\title{
Learning of social studies in elementary school as a medium to strengthen multicultural education in the curriculum era 2013
}

\author{
Yulfia Nora ${ }^{1, *}$ \\ ${ }^{1}$ FKIP, Universitas Bung Hatta, 25171 Padang, Indonesia
}

\begin{abstract}
The writing of this article aims to describe the learning of social studies in elementary schools as a medium to strengthen multicultural education in the era of the curriculum 2013. Writing methods used are qualitative descriptions and literature studies. Social studiesis one of the subjects found in the basic education curriculum. Social studies essentially examines human relationships with the environment. The environment in question here is one of the ethnic, religious, racial, ethnic and linguistic diversity in Indonesian. Become, the context of social studies learning is multicultural education.Multicultural education is a process of developing human potential that values heterogeneity as a consequence of diversity based on the principle of equality, mutual respect, and mutual acceptance and understanding of the moral commitment to bring about social justice. But in fact, social studies learning has not been applied as a medium of multicultural education.Therefore, through the implementation of curriculum 2013 Social studies subjects as a medium to strengthen multicultural education. This is because the implementation of the 2013 curriculum is oriented towards the formation and development of learners' character in diversity.
\end{abstract}

\section{Introduction}

Indonesian is a country of diverse people, composed of various religious, cultural, linguistic, ethnic, racial and ethnic groups. In other words, Indonesian is a multicultural country. It cannot be denied that such diversity can divide unity and unity, even the worst can dispel the sense of nationalism. This is because the community is more concerned with the group than the interests of the nation. The diminishing sense of unity and the decay of nationalism can be seen from the life of Indonesian society today, especially among the young who are strongly influenced by outside cultures, resulting in many behaviors that are inconsistent with the national identity and the number of narrow fanaticism groups that can lead to disharmony in society. In response to these problems, the government and society must overcome and anticipate early one of them through multicultural education.

Multicultural education is not a subject in the curriculum, but multicultural education is a strategy and concept of education based on the utilization of diversity that exists in

* Corresponding author: yulfianora@yahoo.com 
society through learning materials, especially those that exist in learners such as religious diversity, culture, language, social status, gender, ethnicity and race. Multicultural education is education that always upholds values, beliefs, heterogeneity, plurality and diversity, whatever its aspects in society. Thus, multicultural education does not make all human beings homogeneous. Multicultural education is not business-oriented education. Yet as is known that the actual education is not an education that produces mere skills, but education that must accommodate all types of intelligence known as multiple intelligence. In other words, multicultural education is integrated in the subject matter of every subject at school, especially in elementary and secondary schools.

Government efforts to overcome and anticipate problems that occur, because as a multicultural country that makes education as one of the strategic means in efforts to build, develop and maintain the identity of the nation in the current era of globalization. Application of the 2013 curriculum is one of the main means to form and build the character of learners in accordance with the national identity of Pancasila and the 1945 Constitution. This is because the internalization of Pancasila values and the 1945 Constitution is further expanded not only in the subjects of Civics alone but rather integrated in all subjects in school. Thus, that each subject has an important role to shape the character of the learner. Some integrated subjects can also bear a character. One of the compulsory subjects in the elementary school curriculum is the subject of Social Studies.

Social study is a subject that integrates various branches of social science such as economics, sociology, geography and history. Social studies essentially examines events, facts, concepts and generalizations on issues, phenomena and social phenomena. In other words, Social studies examines human relationships with the environment, related to what causes and effects that arise after a social process conducted by humans both individually or in groups, be it cultural, religious, ethnic and other groups. This means that social studies material nuanced or directly related to multicultural education. Thus, social studies can serve as a medium for shaping and developing multicultural education.

\section{Writing method}

The method of writing this article using descriptive qualitative and literature study. In essence descriptive qualitative research is a method in researching the status of a group of people, an object with the aim of making descriptive, picture or painting systematically, factually and accurately about the facts investigated. This descriptive qualitative research aims to describe what is happening today. This means that this study describes, notes, analyzes and interpret the current conditions occur. In other words descriptive qualitative research is aimed to obtain information of existing circumstances. While the literature method is a method of data collection is done by taking the necessary data from the relevant literature.

\section{Discussion}

\subsection{3 curriculum}

The curriculum of 2013 is a change of curriculum structure of KTSP. This change is made of many problems that occur in education and is one effort to improve the curriculum that is less precise to the needs of public education today. Curriculum 2013 or abbreviated as "kutilas" has the main character in which every competence that must be achieved by students are character-filled. 
Competence of SD/MI graduates that are contained in the curriculum of 2013 that is, 1) Attitudes, through curriculum 2013, students are expected to have behaviors that reflect the attitude of believers, noble character, confidence and responsible in effectively interaction with social and natural environment around the house, school and playground. 2) Knowledge, through the 2013 curriculum, students are expected to have the ability of factual and conceptual knowledge in science and technology, art and culture. 3) Skills, through the curriculum 2013, students are expected to have the ability of thought and action effective and creative in the realm of abstract and concrete in accordance with the assigned to learners.

The implementation of the 2013 curriculum, is expected to support better education in the future that considering the many challenges found in the current globalization. This means that 2013 curriculum is expected to filter out the outside culture that goes into the country, so that the identity of the nation can still be maintained. As mentioned earlier that 2013 curriculum has a special characteristic in which each learning material is characterfilled. Characters that are formed and developed in the participants include the mutual acceptance and respect for differences in social life.

In general, the 2013 curriculum has the following characteristics:

a. Develop a balance between the development of spiritual and social attitudes, curiosity, creativity, cooperation with intellectual and psychomotor abilities

b. Schools are part of a community that provides a planned learning experience in which learners apply what is learned in school to community and utilize the community as a learning resource

c. Develop attitudes, knowledge and skills and apply them in various situations in schools and communities

d. Give enough time to develop various attitudes, knowledge and skills

e. Competence is expressed in terms of core competencies of the class detailed in the subject's basic competencies

f. The core competencies of the class are elements of basic competence organizing, in which all basic competencies are developed to achieve core competencies

g. Basic competencies are developed based on accumulative principles, mutual reinforcement between subjects and levels of education.

Based on the above characteristics, the objective of the 2013 curriculum is to prepare Indonesian people to have the ability to live as individuals and citizens who are faithful, productive, creative, innovative and affective and able to contribute to the life of society, nation, state and civilization.

Social studies is one of the subjects contained in the curriculum of 2013, which has an important function to achieve curriculum objectives, especially in shaping and developing the character of learners in accordance with national identity (Pancasila and 1945). Thus the subject becomes an appropriate means for multicultural education.

\subsection{Social studies learning in elementary school}

According to [1] Social studies is a science that examines various disciplines of social sciences and humanities and basic human activities are packed scientifically in order to provide insight and deep understanding to learners, especially at the level Basic and intermediate.

Social studies is a subject that is expected to nurture its members really developed as a rational and responsible social human, so that therefore created values. Social studies learning in elementary school is subjects related to human life, educate, provide stock and train attitude, values, morals, and skills for learners, so that learners can become democratic and responsible Indonesian citizens and citizens of a peace-loving world [1]. In line with 
the opinion of [2] social studies education is an educational program that builds learners to become good citizens in an atmosphere of peace. Indicator, after studying social studies, learners will have a number of competencies that is communicate, adapt, synergize well and always think positive to others.

Social studies learning is a learning that concerns all aspects of relationships in human life. The purpose of IPS learning is the change of behavior and positive behavior of learners with the culture, values, customs and traditions that exist in society. Thus, the context of IPS learning is multicultural education. Multicultural education is a process of developing human potential that values heterogeneity as a consequence of diversity based on the principle of equality, mutual respect, mutual acceptance and understanding of moral commitment to bring about social justice.

Social studies learning in elementary schools should consider the needs and characteristics of learners aged between 6-12 years. Children in the 7-11 years age group according to Piaget are in the development of cognitive abilities at concrete operational level. Concrete operations are the cognitive level by which the child will understand what is learned when looking at concrete objects. This means that even though the subject matter of Social studies in elementary school is the concept material, the teacher must relate the material with everything that can be seen and felt or experienced by the children. Thus, the message of multicultural education can be easily conveyed through social studies learning.

\subsection{Multicultural education}

The context of multicultural life is a multi-dimensional dimensioned understanding that is presented to broaden the discourse of human thought which has been maintaining cultural, religious, and group "egoism". Maintaining a plurality of cultural diversity is a social and political interaction between people of different ways of life and thinking in a society. Maintaining a plurality of cultural diversity is a social and political interaction between people of different ways of life and thinking in a society. Thus, the attitude of multiculturalism should be owned by everyone. The attitude of accepting and appreciating the difference is not automatically developed by itself. Especially because in a person there is a tendency to expect others to be like him [3].

[2] argues that in essence multicultural education is meaningful for preparing all students to work actively toward structural similarities in school organizations and institutions. Multicultural education is not a policy that leads to the institutionalization of inclusive education and teaching through curricula that contribute to individual cultural competition. In addition, multicultural-based learning seeks to empower students to develop respect for people of different cultures, ethnic or race directly. Multicultural education is one of the strategies presented in education to understand the reality condition of Indonesian society that is rich in diversity in various dimensions of life.

The mutual acceptance and attitude for different cultures, religions, races and ethnic groups will develop if trained and taught to learners through multicultural education. Multicultural education is not a subject taught in schools, but integrated multicultural education in every subject. Through the education system, then multicultural education is planned well that is contained in the curriculum and elaborated in the form of competence for each subject matter that contains character according to the values of national identity. In other words, multicultural education is an effort to teach the diversity that exist in Indonesia such as the existence of Sundanese, Javanese, Minang, Batak, Ambon and others. And because of its cultural contents, among others arts, traditional clothing and custom homes as which are taught in the subjects of social studies, multicultural it is teach various instruments, clothing and custom homes every region in Indonesian [4]. 
Multicultural education is a proper and proper education for all learners. This is because the main purpose of multicultural education are; 1) eliminating educational discrimination means giving equal opportunity for each learner to develop his potential, 2) make learners can achieve academic achievement according to their potential, 3) make learners aware of social and active as citizens of local, national and global community. Obviously this goal must be achieved given the enormous external cultural influences on the development of behavior of the younger generation (students). To achieve the goals of multicultural education, the role and skills of teachers is needed in teach any learning materials that contain aspects of multicultural education. Hanum and Sisca [5] argue that multicultural education at least concerns three things: 1) awareness of the important value of cultural diversity, awareness of diversity contributes to the personal development of students, 2) educational reform movement, meaning that multicultural education is not merely an educational program, but covers all aspects of education.

Among the skills of teachers that can be applied of the teach multicultural is the ability of teachers to find and convey multicultural messages through learning materials in each subject, especially on social studies materials. Social studies is a subject where the material is directly related to multicultural, especially in primary school. In order for teachers to convey multicultural messages properly, teachers need to use varied and innovative learning models. Sagala (2010, p.176) suggests that the learning model is a conceptual framework that contains systematic procedures and organizes certain learning experiences that serve as teacher guides in the teaching and learning process. In addition to using the learning model, teachers can also use the module as a tool to convey the message of multicultural education.

The research of [5] on the implementation of multicultural learning models in elementary schools using a module, concluded that most teachers already have readiness to convey multicultural messages to students. And even most teachers argue that multicultural education can be applied in everyday life as well as developed modules integrated with social studies subjects can be used as a tool to cultivate multicultural education in elementary schools. Further research results [6] also concluded that "multicultural learning model for elementary school is integrated multicultural learning using modules can be accepted and established by teachers as a model of multicultural learning applied in schools integrated with social studies material and supported by material modules Teach as a relevant material supplement ". Further research results revealed that the project-based multicultural education learning module can also improve learning outcomes of students [7].

It can be concluded that the subjects of social studies is a medium to strengthen multicultural education considering the social studies learning materials in elementary schools is directly related to multicultural education. As an example of concrete social studies material learning such as the role material and position of a person in the family, community and country. The material of cultural diversity teaches learners to recognize and appreciate other cultures. The material about heroes can be used as role models for students to live their lives.

\section{Conclusion and recommendation}

\subsection{Conclusion}

Based on the discussion, it can be concluded that (1) the main characteristics of the 2013 curriculum are characterized. One of the characters in question is the attitude of accepting and respecting religious, cultural, racial and ethnic differences. (2) multicultural 
education is a solution for the people of Indonesia to maintain and uphold the national identity of the Pancalisa and the 1945 Constitution in the current global era. (3) Social studies learning is a learning that is directly related to multicultural education, especially in elementary schools. (4) A teacher must be able to find and convey the message of multicultural education contained in every learning material especially on social studies learning materials. (5) Teachers can use various models of learning, approach or module as a tool to achieve learning objectives.

\subsection{Recommendation}

Based on the conclusion, the authors suggest to teachers in elementary schools to relate learning materials social studies with concrete situations so that learners can easily understand what the teacher submitted. Teachers are also skilled at discovering and conveying the message of multicultural education through social studies learning materials. In addition, teachers are also advised to use various learning models, approaches or modules as a tool to achieve learning objectives.

\section{References}

1. A. Susanto, Proses Belajar Mengajar (Kencana Prenadamedia Group, Jakarta, 2014).

2. Sudrajat, Jurnal JIPSINDO 1 (2014).

3. R. Ibrahim, Jurnal Pendidikan Islam El-Carbawi 1(2008).

4. Tatang M. Amirin, Jurnal Pembengunan Pendidikan: Fondasi dan Aplikasi 1 (2012).

5. F. Hanum, S. Rahmadonna, Jurnal Penelitian Ilmu Pendidikan 1 (3) (2010).

6. F.Hanum, S.Raharja, Jurnal Penelitian Ilmu Pendidikan 2 (6) (2013).

7. L. Prastyawati, F. Hanum, Harmoni Sosial: Jurnal Pendidikan IPS 1 (2) (2015). 